\title{
DIAGNOSA PENYAKIT AIDS, MERS VIRUS DAN EBOLA BERBASIS WEB DI PUSKESMAS SIKO TERNATE
}

\section{DIAGNOSIS OF DISEASE AIDS, MERS VIRUS AND EBOLA WEB BASED IN PUSKESMAS SIKO TERNATE}

\author{
Randi Djoge ${ }^{1}$, Kamarullah Hasan ${ }^{2}$ \\ Program Studi Teknik Komputer \\ Akademi Ilmu Komputer (AIKOM) Ternate \\ randi_djoge11@gmail.com
}

\begin{abstract}
Abstrak
Puskesmas Siko ternate merupakan salah satu pusat layanan kesehatan untuk masyarakat yang berada disekitar daerah tersebut, dalam menyediakan informasi gejala-gejala penyakit masih konvensional serta pelayanan pemeriksaan penyakit Aids, Mers dan Ebola masih belum efektif jika masyarakat yang ingin mengetahui informasi lebih jelas harus datang untuk bertanya informasi gejala ke puskesmas tersebut dan ingin melakukan pemeriksaan jika dokter yang berhalangan hadir maka kegiatan tersebut dapat terhambat, sehingga dianggap kurang efisien dan memerlukan satu sistem yang memilki kepakaran yang dapat menunjang kegiatan tersebut, Penelitian ini dilakukan di puskesmas Siko ternate, bertujuan merancang sistem pakar yang dapat mendiagnosa penyakit Aids, Mers dan Ebola berbasis Web, Metode pengumpulan data menggunakan observasi, wawancara serta metode inferensi forward chaining, Model Pengembangan Sistem menggunkan model Waterfall dengan pendekatan desain sistem diagram flow data (DFD), Bahasa Pemrograman yang digunakan HTML, PHP, dan $M y S Q l$ sebagai databasenya. Dengan adanya sistem ini diharapkan petugas dapat menyediakan informasi pada sistem yang efisien dan mempermudah petugas dalam melakukan diagnosa mengenai penyakit Aids, Mers dan Ebola di Puskesmas Siko Ternate
\end{abstract}

Kata kunci: Diagnosa Penyakit, Sistem Pakar, Website

\begin{abstract}
Puskesmas Siko Ternate is one of the health service centers for the people around the area, in providing information on conventional disease symptoms as well as Aids disease screening services, Mers and Ebola are still not effective if people who want to know more information should come to inquire symptom information to the Puskesmas and want to check if an absent doctor is present then the activity may be hampered, so it is considered less efficient and requires a system that has expertise that can support these activities, This research was conducted at the health center of Siko ternate aims to design an expert system that can diagnose Aids, Mers and Ebola-based Web diseases, Methods of data collection using observation, interview and forward chaining inference method, System Development Model uses Waterfall model with system flow diagram data flow design (DFD) design approach, Programming Language used HTML, PHP, and MySQL as the database. With this system is expected officers can provide information on an efficient system and facilitate the officer in diagnosing the disease Aids, Mers, and Ebola in Puskesmas Siko Ternate
\end{abstract}

Keywords: Disease Diagnosis, Expert Sistem, Website 


\section{PENDAHULUAN}

Dengan perkembangan teknologi informasi dan komunikasi dapat memberikan dampak yang sangat besar terhadap kehidupan manusia sehari-hari serta kerja organisasi maupun instansi, berbagai perangkat yang disediakan dalam membantu kinerja masing-masing agar lebih efisien dalam mengerjakan dan menyediakan informasi dan melakukan pekerjaan tanpa ahlinya tersebut salah satu adalah sistem pakar atau expert sistem.

Sistem pakar (expert system) adalah sistem yang berusaha mengapdosi pengetahuan manusia ke komputer, agar komputer dapat menyelesaikan masalah seperti yang biasa dilakukan oleh para ahli. Sistem pakar yang baik dirancang agar dapat menyelesaikan suatu permasalahan tertentu dengan meniru kerja dari para ahli. Dengan sistem pakar, orang awam pun dapat menyelesaikan masalah yang cukup rumit yang sebenarnya hanya dapat diselesaikan dengan bantuan para ahli. Bagi para ahli, sistem pakar juga akan membantu aktivitasnya sebagai asisten yang sangat berpengalaman

Dengan adanya sistem pakar maka muncul berbagai solusi yang diberikan dalam membantu organisasi dan instansi dalam mendukung kinerjanya salah satu yang ada pada bidang kesehatan dalam menyediakan informasi serta dapat melakukan diagnosa mengenai penyakit tersebut seperti Aids, Mers dan Ebola

Aids, Mers dan Ebola adalah suatu penyakit yang belum ada obatnya dan belum ada vaksin yang bisa mencegah serangan virus tersebut, sehingga penyakit ini merupakan salah satu penyakit yang sangat berbahaya bagi kehidupan manusia baik sekarang maupun waktu yang datang. Selain itu penyakit ini juga dapat menimbulkan penderitaan, baik dari segi fisik maupun dari segi mental. Ada baiknya mungkin kita sering mendapat informasi melalui media cetak, elektronik, ataupun seminar-seminar

Puskesmas Siko ternate merupakan salah satu pusat layanan kesehatan untuk masyarakat yang berada disekitar daerah tersebut, dalam menyediakan informasi gejala-gejala penyakit masih konvensional serta pelayanan pemeriksaan penyakit Aids, Mers dan Ebola masih belum efektif kekurangannya jika masyarakat yang ingin mengetahui informasi lebih jelas harus datang melihat ke puskesmas tesebut dan ingin melakukan pemeriksaan jika dokter yang berhalangan hadir maka kegiatan tersebut dapat terhambat, sehingga dianggap kurang efisien dan memerlukan satu sistem pakar yang dapat menunjang kegiatan tersebut

Berdasarkan uraian sebelumnya maka diperlukan satu sistem pakar yang dapat menyediakan informasi serta dapat melakukan diagnose terhadap penyakit aids, mers dan ebola mengunakan website, website digunakan agar masyarakat yang ingin mengetahui informasi dan memeriksa gejalan tersebut tidak perlu datang ke puskesmas, dapat melihat informasi dan melakukan mendiagnosa di sistem dimana saja

\section{Rumusan Masalah}

Berdasarkan uraian pada latar belakang masalah sebelumnya, maka dapat dirumuskan pokok permasalahan penelitian adalah: bagaimana merancang sistem pakar pada Puskesmas Siko Ternate agar dapat diagnosa penyakit aids, mers dan ebola berbasis web dengan menggunakan metode forward chaining dengan menggunakan Bahasa 
Pemrograman HTML, PHP serta MySQL sebagai data basenya

\section{LANDASAN TEORI}

\section{Pengertian Sistem}

Menurut Jogiyanto (2003:34), Sistem dapat didefinisikan dengan pendekatan prosedur dan pendekatan komponen. Dengan pendekatan prosedur, sistem dapat didefinisikan sebagai kumpulan dari prosedur-prosedur yang mempunyai tujuan tertentu. Contoh sistem yang didefinisikan dengan pendekatan prosedur ini adalah sistem akuntansi. Sistem ini didefinisikan sebagai kumpulan dari prosedur-prosedur penerimaan kas, pengeluaran kas, penjualan, pembelian dan buku besar. Sedangkan dengan pendekatan komponen, sistem dapat didefinisikan sebagai kumpulan dari komponen yang saling berhubungan satu dengan yang lainnya membentuk satu kesatuan untuk mencapai tujuan tertentu. Contoh sistem yang didefinisikan dengan pendekatan ini misalnya adalah sistem komputer yang didefinisikan sebagai kumpulan dari perangkat keras dan perangkat lunak

\section{Pengertian Informasi}

Informasi menurut Turban et al [2] merupakan data yang telah diorganisir sehingga memberikan arti dan nilai kepada penerimanya. Sedangkan menurut Jogiyanto, Informasi adalah data yang diolah menjadi bentuk yang lebih berguna dan lebih berarti bagi yang menerimanya. Dapat dikatakan bahwa data merupakan bahan mentah, sedangkan informasi adalah bahan jadi atau bahan yang telah siap digunakan, Jadi, sumber dari informasi adalah data.

\section{Pengertian Sistem Informasi}

Menurut Ladjamudin (2005:13) Sistem Informasi dapat didefinisikan sebagai berikut:

a. Suatu sistem yang dibuat oleh manusia yang terdiri dari komponen-komponen dalam organisasi untuk mencapai suatu tujuan yaitu menyajikan informasi.

b. Sekumpulan prosedur organisasi yang pada saat dilakasanakan akan memberikan informasi bagi pengambilan keputusan dan/atau untuk mengendalikan organisasi.

c. Suatu sistem di dalam suatu organisasi yang mempertemukan kebutuhan pengolahan transaksi, mendukung operasi, bersifat manajerial, dan kegiatan strategi dari suatu organisasi dan menyediakan pihak luar tertentu dengan laporan-laporan yang diperlukan.

\section{Sistem Pakar}

Sistem pakar (expert system) adalah sistem yang berusaha mengadopsi pola pikir manusia untuk selanjutnya di implementasikan dalam sebuah perangkat lunak, agar komputer dapat menyelesaikan masalah seperti yang biasa dilakukan oleh para ahli. Sistem pakar yang baik dirancang agar dapat menyelesaikan suatu permasalahan tertentu dengan meniru kerja dari para ahli. Dengan sistem pakar ini, orang awampun dapat menyelesaikan masalah yang cukup rumit yang biasanya hanya dapat diselesaikan dengan bantuan para ahli.

Sistem pakar pertama kali dikembangkan oleh komunitas Artificial Intelligence (AI) pada pertengahan tahun 1960 an. sistem pakar yang muncul pertama kali adalah General-purpose Problem Solver (GPS) yang dikembangkan oleh Newel dan Simon. 
GPS (dan program-program yang serupa) ini mengalami kegagalan dikarenakan cakupannya terlalu luas yang mengakibatkan pengetahuan- pengetahuan penting seringkali menjadi tertinggal

\section{Keuntungan Sistem Pakar}

Sistem pakar mampu memecahkan masalah tanpa dipengaruhi oleh faktor dari luar seperti intimidasi, paksaan kejiwaan, faktor ekonomi atapun perasaan. Berikut ini beberapa keuntungan dari syitem pakar:

1. Memungkinkan orang awam bisa mengerjakan pekerjaan para ahli.

2. Bisa melakukan proses secara berulang secara otomatis.

3. Menyimpan pengetahuan dan keahlian para pakar.

4. Mampu mengambil dan melestarikan keahlian para pakar (terutama yang termasuk keahlian langka).

5. Mampu beroperasi dalam lingkungan yang berbahaya.

6. Memiliki kemampuan untuk bekerja dengan informasi yang tidak lengkap dan mengandung ketidakpastian.

7. Tidak memerlukan biaya saat tidak digunakan, sedangkan pada pakar manusia memerlukan biaya sehari-hari.

8. Dapat digandakan (diperbanyak) sesuai kebutuhan dengan waktu yang minimal dan sedikit biaya.

9. Dapat memecahkan masalah lebih cepat daripada kemampuan manusia dengan catatan menggunakan data yang sama.

10. Menghemat waktu dalam pengambilan keputusan.

11. Meningkatkan kualitas dan produktivitas.

\section{Metode Inferensi}

Metode inferensi merupakan suatu cara penarikan kesimpulan yang dilakukan oleh mesin inferensi untuk menyelesaikan masalah. Ada dua metode inferensi yang penting dalam sistem pakar, yaitu runut maju (forward chaining) dan runut balik (backward chaining). Salah satu contoh Forward Chaining adalah suatu strategi pengambilan keputusan yang dimulai dari bagian premis (fakta) menuju konklusi (kesimpulan akhir) (Kusrini, 2006).

\section{Pemrograman PHP}

PHP adalah singkatan dari Hypertext Processor, yang merupakan sebuah bahasa scripting yang terpasang pada HTML. Tujuan utama PHP adalah untuk membuat sebuah web yang dinamis.Web dinamis merupakan web yang didalamnya terdapat masukan, proses, dan keluaran. Halaman web biasanya disusun dari kode-kode html yang disimpan dalam sebuah file berekstensi. File html ini dikirimkan oleh server atau file ke browser, kemudian browser menterjemahkan kode-kode tersebut. PHP menyatu dengan tag HTML, dieksekusi di server dan digunakan untuk membuat halaman web yang dinamis seperti ASP (Active Server Pages) dan JSP (Java Server Pages). PHP dapat berjalan di berbagai sistem operasi seperti windows 98/NT, UNIX/LINUX, solaris maupun macintosh

\section{Pengertian Mysql}

MySQL (My Structure Query Language) termasuk database relasional (RDBMS), dan berbasis SQL dengan menggunakan konsep client-server, kelebihan dari $M y S Q L$ adalah cepat, kuat, serta mudah digunakan, sehingga kita dapat dengan mudah menyimpan, mengubah, dan mengakses data dan informasi. MySQL (My Structure Query Language) adalah sebuah program pembuat database yang bersifat open 
source, artinya siapa saja boleh menggunakannya dan tidak dicekal atau dengan kata lain gratis, MySQL merupakan database yang bersifat online sehingga dapatdigunakan untuk aplikasi Multi User

\section{METODE PENELITIAN}

\section{Penelitian Pustaka (Library Research)}

Penelitian ini merupakan kajian teoritis yang berhubungan dengan penyusunan tugas akhir, dalam hal penulis menggunakan beberapa buku sebagai referensi

\section{Penelitian Lapangan (Field Research)}

Penelitian lapangan adalah jenis pengumpulan data dengan melakukan pengamatan langsung dilapangan, dengan menggunakan teknik sebagai berikut:

a. Teknik Observasi adalah teknik yang dilakukan dengan cara mengadakan pengamatan secara langsung mengenai sistem di lapangan. Observasi ini dapat dilanjutkan dengan evaluasi dalam arti secara menyeluruh yang menyangkut dengan input, proses dan hasil.

b. Teknik wawancara ( interview) adalah dengan melakukan wawancara dengan pimpinan atau staf untuk mendapatkan data berhubungan dengan Penelitian

\section{Metode Pengembangan Sistem}

Metode air terjun atau yang sering disebut metode waterfall sering dinamakan siklus hidup klasik (classic life cycle), dimana hal ini menggambarkan pendekatan yang sistematis dan juga berurutan pada pengembangan perangkat lunak, dimulai dengan spesifikasi kebutuhan pengguna lalu berlanjut melalui tahapan-tahapan perencanaan (planning), permodelan (modeling), konstruksi (construction), serta penyerahan sistem ke para pelanggan/pengguna (deployment)

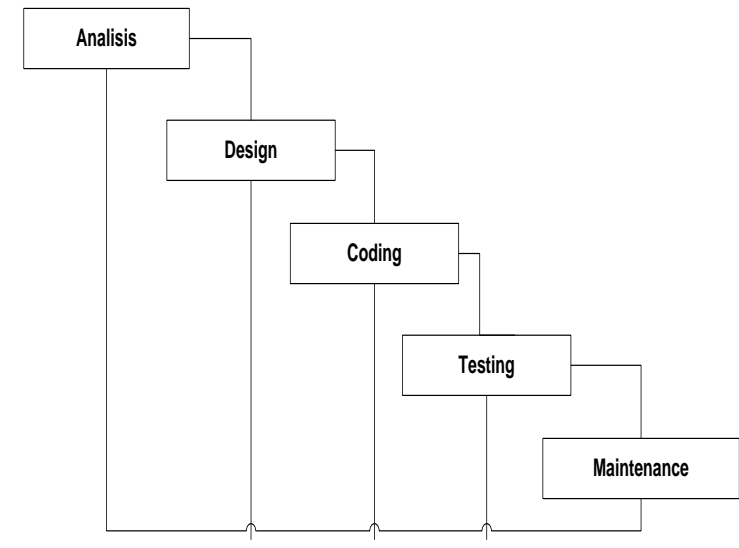

Gambar 1. Model Waterfall

\section{Kebutuhan Fungsional}

Admin melakukan Login, mengelola database sistem, melakukan diagnosa penyakit serta mencetak laporan hasil diagnosa

\section{Kebutuhan Non-Fungsional}

Kebutuhan perangkat keras yang memadai tentu sangat menunjang kinerja dari program ini.Hadware dan Software yang dibutuhkan untuk menjalankan program aplikasi yang dibangun speksifikasi kebutuhan sebagai berikut:

1. Processor Intel core(TM)2

2. Memory $1.00 \mathrm{~GB}$ (893 MB Usable)

3. Harddisk $160 \mathrm{~GB}$

4. CD Room Samsung 42x

5. Monitor, Keyboard, Mouse

6. Printer

Untuk mendukung Perancangan mendiaknosa penyakit Aids, mers virus dan ebola berbasis web pada puskesmas siko kota ternate tersebut selain diperlukan perangkat keras juga dibutuhkan perangkat lunak. Perangkat lunak yang dibutuhkan untuk mendukung sistem ini adalah dengan menggunakan aplikasi PHP, MySql dan Adobe Dreamweaver sebagai DataBasenya.

\section{Kerangka Penilitian}

Kerangka penelitian merupakan urutan langkah-langkah tahapan penelitian yang 
akan dilakukan, berikut merupakan gambar urutan kerangka penilitian

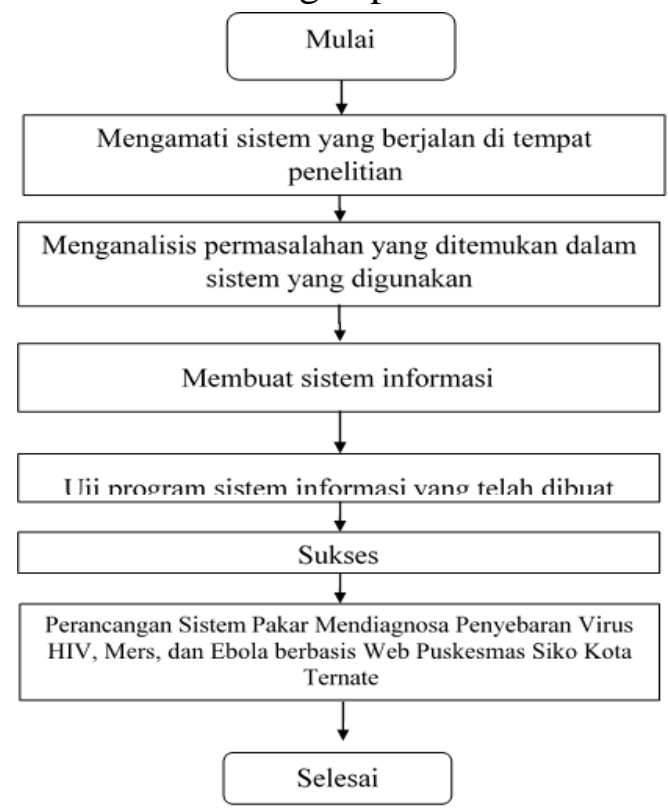

Gambar 2. Kerangka Penilitian

\section{Analisa Sistem yang Berjalan}

Sistem yang berjalan merupakan rancangan hasil analisa sistem yang digunakan pada puskesmas siko tersebut, berikut merupakan gambar flowchart sistem yang berjalan:

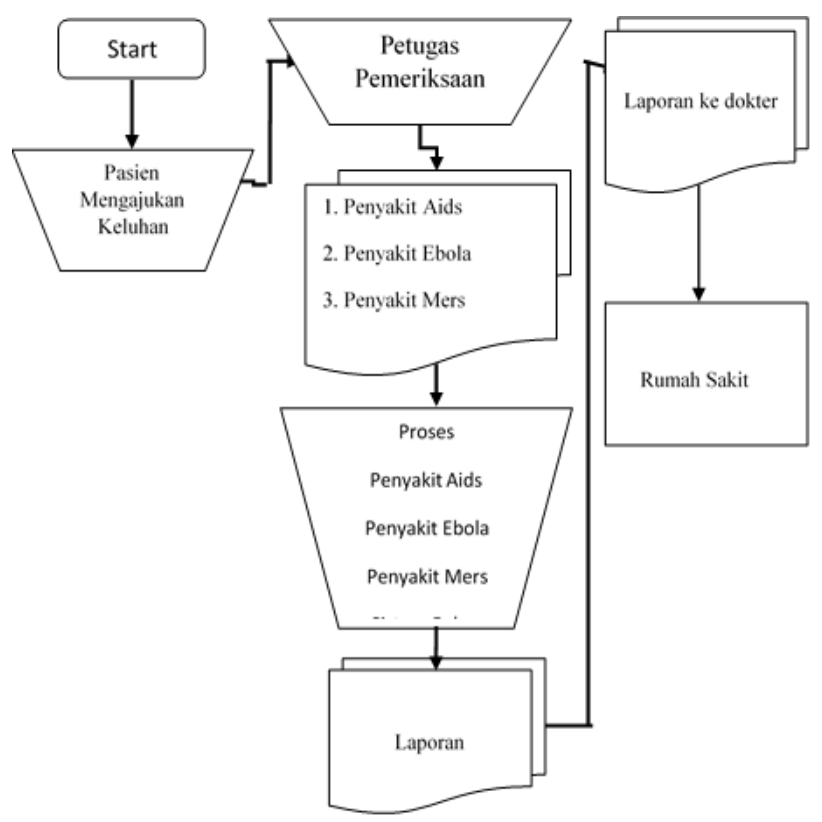

Gambar 3. Sistem yang berjalan
Berdasarkan sistem yang berjalan maka peneliti mengusulkan sistem yang baru. Berikut desain flowchart sistem yang diusulkan.

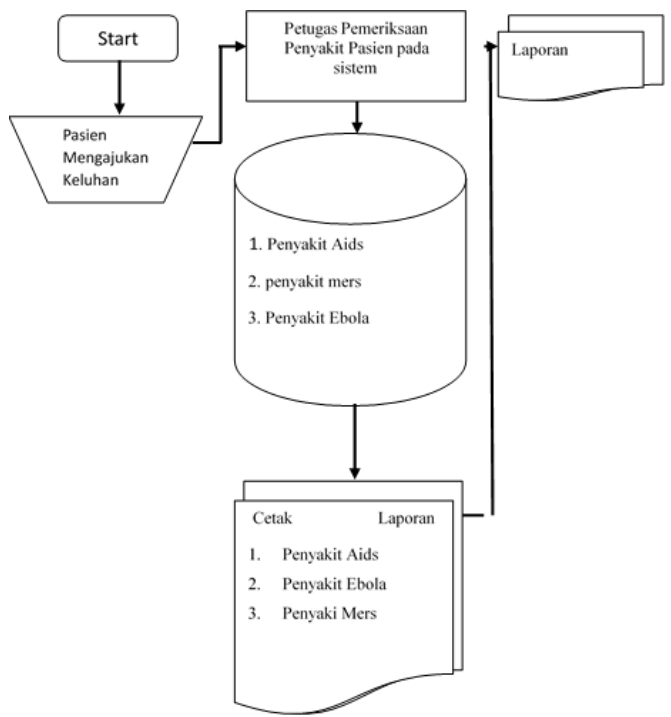

Gambar 4. Flowchart Sistem Yang Diusulkan

\section{PERANCANGAN SISTEM}

\section{Perancangan Tabel Database}

Perancangan tabel database merupakan rancangan kamus data sistem yang akan digunakan sebagai database dalam menjalankan aplikasi pada sistem

Tabel 1. Tabel_Penyakit

\begin{tabular}{|l|l|l|l|l|}
\hline $\begin{array}{c}\text { Nama_Fie } \\
\text { ld }\end{array}$ & Type & $\begin{array}{c}\text { Widt } \\
\mathrm{h}\end{array}$ & Index & $\begin{array}{l}\text { Keterang } \\
\text { an }\end{array}$ \\
\hline Id & Int & 11 & $\begin{array}{l}\text { Primar } \\
\text { y key }\end{array}$ & $\begin{array}{l}\text { Id } \\
\text { penyakit }\end{array}$ \\
\hline Nama & $\begin{array}{l}\text { Varcha } \\
\text { rt }\end{array}$ & 50 & & $\begin{array}{l}\text { nama } \\
\text { penyakit }\end{array}$ \\
\hline
\end{tabular}

Tabel 2. Tbl_tmp

\begin{tabular}{|l|l|l|c|l|}
\hline Nama_Field & Type & Width & Index & Keterangan \\
\hline Id & Int & 11 & $\begin{array}{c}\text { Primary } \\
\text { key }\end{array}$ & Id penyakit \\
\hline Detail & Int & 11 & & $\begin{array}{l}\text { Detail } \\
\text { penyakit }\end{array}$ \\
\hline Penyakit & Int & 11 & & Penyakit \\
\hline Post & Int & 11 & & $\begin{array}{l}\text { Post } \\
\text { penyakit }\end{array}$ \\
\hline
\end{tabular}

\section{Rancangan System yang Diusulkan}


Tabel 3. Tbl_Gejala

\begin{tabular}{|l|l|l|l|l|}
\hline $\begin{array}{c}\text { Nama_Fi } \\
\text { eld }\end{array}$ & Type & $\begin{array}{c}\text { Widt } \\
\mathrm{h}\end{array}$ & Index & Keterangan \\
\hline Id & Int & 11 & $\begin{array}{c}\text { Prima } \\
\text { ry key }\end{array}$ & Id gejala \\
\hline Nama & $\begin{array}{l}\text { varch } \\
\text { ar }\end{array}$ & 50 & & $\begin{array}{l}\text { Nama_gejal } \\
\text { a }\end{array}$ \\
\hline penyakit & Int & 11 & & Penyakit \\
\hline Detail & Int & 11 & & $\begin{array}{l}\text { Detail_Peny } \\
\text { akit }\end{array}$ \\
\hline
\end{tabular}

Tabel 4. Tbl_pencegahan

\begin{tabular}{|l|l|l|l|l|}
\hline $\begin{array}{c}\text { Nama_Fi } \\
\text { eld }\end{array}$ & Type & $\begin{array}{c}\text { Wid } \\
\text { th }\end{array}$ & Index & Keterangan \\
\hline Id & Int & 11 & $\begin{array}{c}\text { Prima } \\
\text { ry } \\
\text { key }\end{array}$ & Id Pencegahan \\
\hline Nama & $\begin{array}{l}\text { Varc } \\
\text { ar }\end{array}$ & 50 & & $\begin{array}{l}\text { Nama_Penceg } \\
\text { ahan }\end{array}$ \\
\hline Penyakit & Int & 11 & & Penyakit \\
\hline Detail & Int & 11 & & $\begin{array}{l}\text { Detail } \\
\text { Penyakit }\end{array}$ \\
\hline
\end{tabular}

Tabel 5. Tbl_pakar

\begin{tabular}{|l|l|l|l|l|}
\hline $\begin{array}{c}\text { Nama_Fie } \\
\text { ld }\end{array}$ & Type & $\begin{array}{c}\text { Widt } \\
\mathrm{h}\end{array}$ & Index & Keterangan \\
\hline Id & Int & 11 & $\begin{array}{c}\text { Primar } \\
\text { y key }\end{array}$ & Id_Pakar \\
\hline tanggal & Date & $\begin{array}{l}\text { Tanggal } \\
\text { daftar }\end{array}$ \\
\hline Nama & $\begin{array}{l}\text { Varc } \\
\text { ar }\end{array}$ & 50 & & $\begin{array}{l}\text { Nama_pasie } \\
\text { nam }\end{array}$ \\
\hline Alamat & $\begin{array}{l}\text { Varc } \\
\text { ar }\end{array}$ & 50 & & $\begin{array}{l}\text { Alamat_pasi } \\
\text { en }\end{array}$ \\
\hline Telp & $\begin{array}{l}\text { Varc } \\
\text { ar }\end{array}$ & 30 & & $\begin{array}{l}\text { Telpon } \\
\text { pasien }\end{array}$ \\
\hline penyakit & Int & 11 & & $\begin{array}{l}\text { Penyakit } \\
\text { Pasien }\end{array}$ \\
\hline
\end{tabular}

\section{Diagram Konteks}

Diagram konteks merupakan diagram rancangan sistem secara umum dimana konsep pada sistem akan berinteraksi denga user atau pemakai dalam menjalankan sistem tesebut, berikut merupakan diagram konteks sistem pakar diagnose penyakit

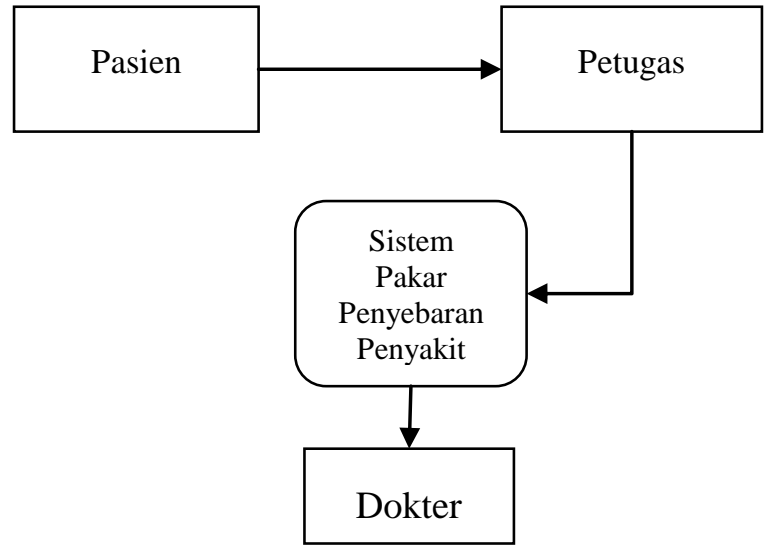

Gambar 5. Diagram Konteks

\section{DFD Level 0}

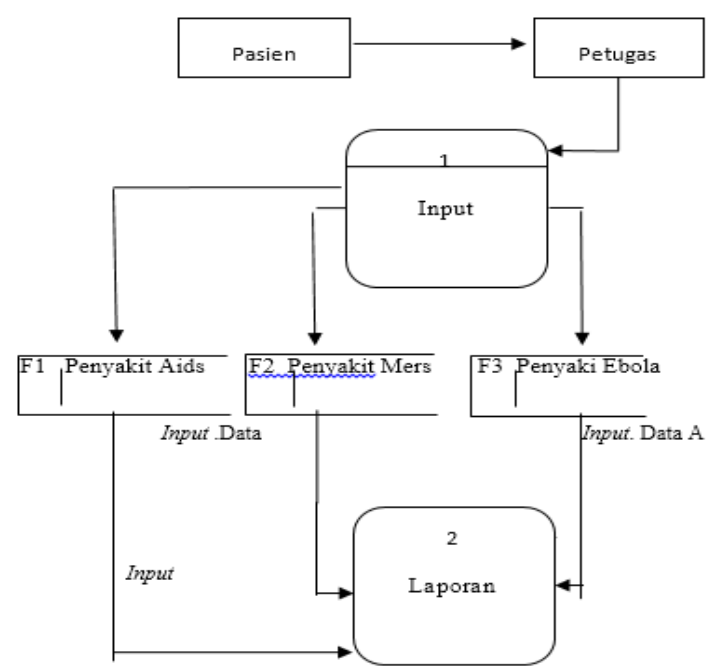

Gambar 6. Diagram Level 0

\section{IMPLEMENTASI SISTEM}

Implementasi sistem merupakan tahapan dalam pengembangan sistem dimana sistem yang sudah dianalisa sebelumnya, dirancang dan ditransformasikan kedalam bahasa pemrograman akan diletakkan dan diujicobakan berdasarkan hasil rancangan tersebut, berikut merupakan hasil gambar impelementasi sistem

\section{Tampilan Home}

Tampilan home merupakan tampilan awal sistem dimana sistem menampilkan 
beberapa informasi dan beberapa menu diawal halaman, berikut merupakan gambar tampilan home

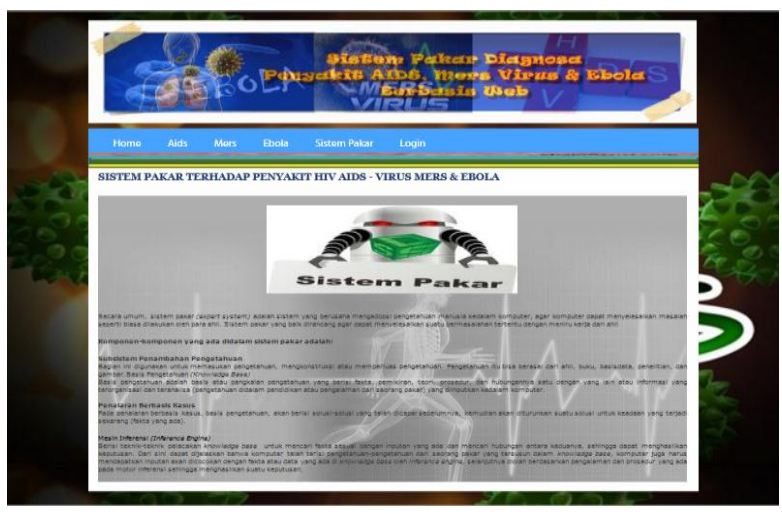

Gambar 7. Tampilan home

\section{Halaman Login Admin}

Halaman admin merupakan tampilan form menu dimana admin dapat melakukan login pada sistem, berikut merupakan gambar tampilan menu admin

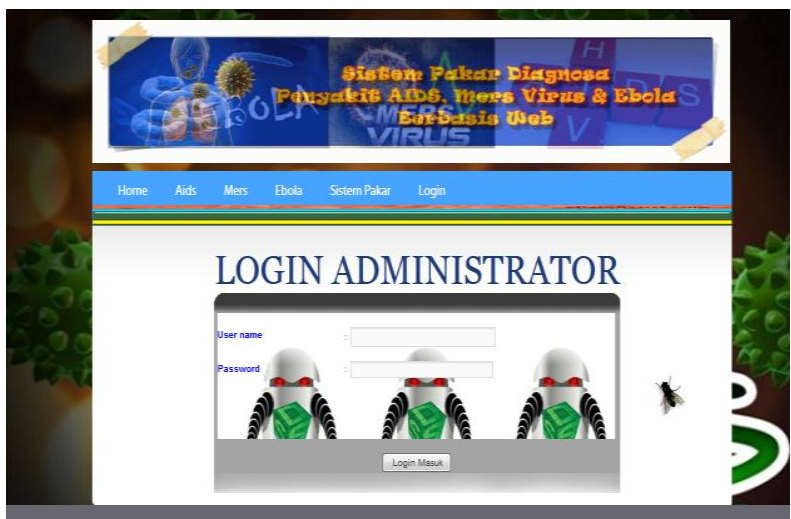

Gambar 8. Menu login

\section{Form Data Penyakit}

Form data penyakit merupakan tampilan halaman menu untuk menampilkan informasi data penyakit, berikut merupakan gambar tampilan form data penyakit

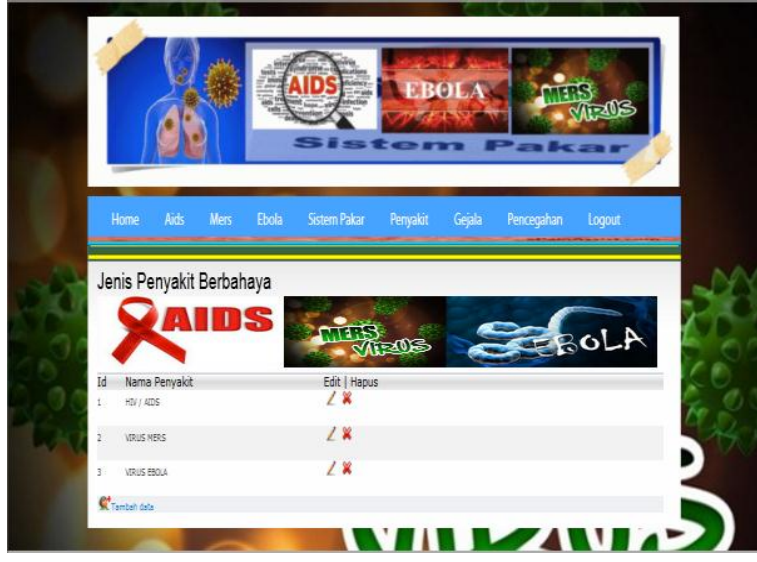

Gambar 8. form data penyakit

\section{Form Data Gejala}

Form data gejala merupakan tampilan menu halaman informasi data gejala, yang akan dimasukan pada menu tesebut, berikut merupakan gambar form informasi data gejala

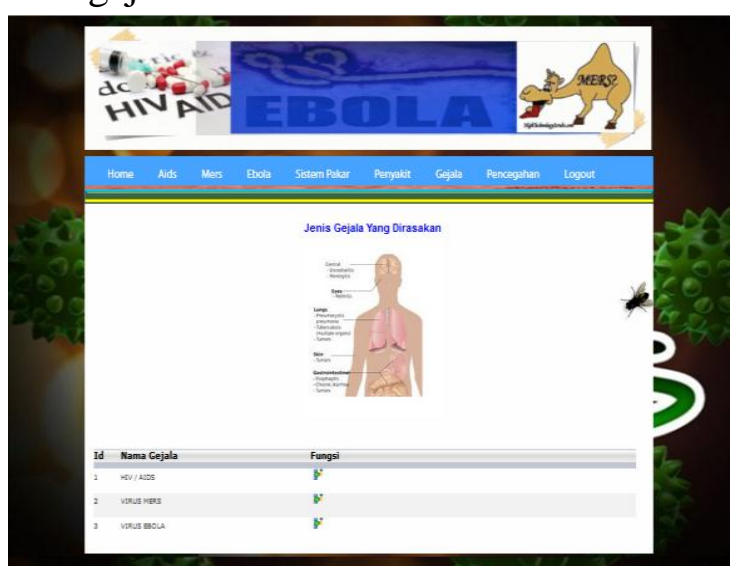

Gambar 9. form data gejala

\section{Form Data Pencegahan}

Form data pencegahan merupakan tampilan menu untuk melihat informasi data pencegahan yang dilakukan setelah dilakukan diagnose, berikut merupakan gambar menu tampilan informasi data pencegahan 


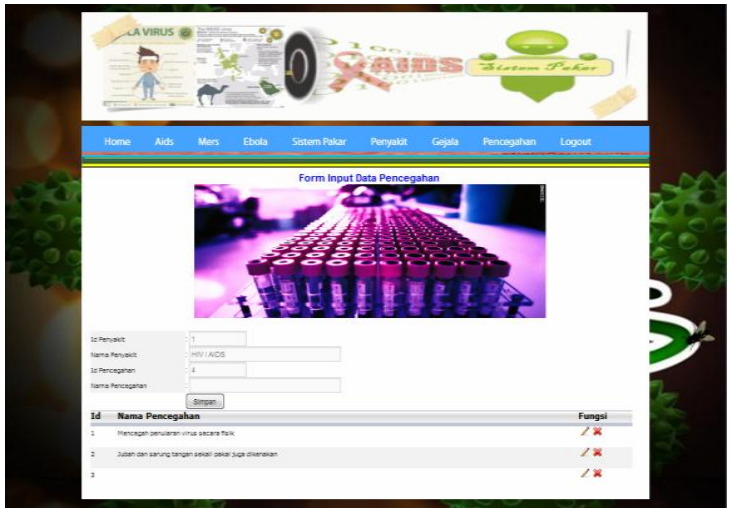

Gambar 10. form data pencegahan

\section{KESIMPULAN}

Ada beberapa hal yang dapat disimpulkan dalam penelitian ini, diantarannya adalah: 1) dapat mempermudah petugas dalam melakukan diagnosa penyakit aids, mers dan ebola pada sistem. 2). Dapat mempermudah masyarakat mendapatkan informasi mengenai penyakit aids, mers dan ebola pada sistem

Berdasarkan kesimpulan tersebut maka diajukan saran sebagai berikut: 1). Aplikasi tesebut hanya sebagai penunjang diagnose penyakit aids, mers dan ebola, perlu adanya hasil dignosa berikut dari dokter ahli dari penyakit tersebut. 2). Perlunya dilakukan Training dan kepada para pengguna sistem tentang pemakaian sistem

\section{DAFTAR PUSTAKA}

Utami Yudi 2001. Perancangan sistem Informasi Berbasis Web,

Jogiyanto. 2003. Sistem Teknologi Informasi. Yogyakarta: ANDI.

Ladjamudin, B. A. 2005. Analisis dan Desain Sistem Informasi. Yogyakarta: GRAHA ILMU

Peranginangin, Kasiman (2006). Aplikasi

Web dengan PHP dan MySQL

Yogyakarta: Penerbit Andi Offset
Kusrini. (2006). Sistem Pakar Teori dan Aplikasi. Yogyakarta: Penerbit Andi Yogyakarta

Madcoms, 2007, Aplikasi Manajemen Database Pendidikan Berbasis Web dengan PHP dan MySQL Penerbit Andi, Yogyakarta

Turban, Leidner, McLean, and Wetherbe, Information Technology for Management, 6th ed.: John Wiley \& Sons (Asis) Pte Ltd, 2008

Evi Nurfitriani 2008 sistem pakar diagnosa penyakit kulit

Irman Hariman 2009, sistem pakar untuk Mendiagnosa penyakit dbd (demam Berdarah dengue) dengan metode Forward chaining Berbasis web

Saputra, Agus. 2013. Proyek Membuat Website Periklanan Dengan PHP. Cirebon: Sinar Kreatif

Muhammad Dahria, Pengembangan Sistem Pakar Dalam Membangun Suatu Aplikasi, jurnal SAINTIKOM, Volume 10, Nomor 3 September 2011 Mardi Turnip, Sistem Pakar Diagnosa Penyakit THT Menggunakan Metode Backward Chaining, Riau Journal Of Computer Science Vol.1/No.1/2015 : 1- 8

Rizky Ambarita, Sistem Pakar Diagnosa Kerusakan Mainboard Komputer, IJIS - Indonesian Journal On Information System, Volume 2 Nomor 1 April 2017, ISSN 25486438 (online) 